Jacek RUSZCZYŃSKI

INoR WT UKSW Warszawa

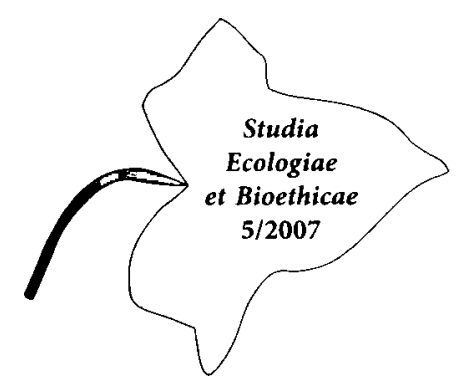

\title{
Traktat o kobiecie
}

\section{Kobieta i piękno}

Scholastyka uznała piękno za własność transcendentalną bytu. Pierwszy tę tezę przyjął Bonawentura. Taka wizja była $\mathrm{z}$ pewnością związana $\mathrm{z}$ podejściem mistycznym. To mistycy dostrzegali zawsze znaczącą rolę piękna w życiu człowieka.

Piękno jest własnością transcendentalną bytu. Jako własność transcendentalna piękno jest zawarte $\mathrm{w}$ istnieniu. Piękno stanowi przejaw istnienia. Istnienie stworzone przez Boga przyczynuje istotę bytu. Osobowe własności istnienia (prawda, dobro i piękno) przyczynują duchowość istoty. Prawda przyczynuje rozum (intelekt), dobro staje się przyczyną woli, zaś piękno sprawia uczucia i życie.

Piękno stanowi przyczynę naszej zmysłowości. Ludzka zmysłowość nie powstałaby bez udziału piękna. Bez udziału piękna nie powstałaby cała nasza uczuciowość. Piękno przyczynuje wszystko, co zmysłowe. Piękno stanowi również przyczynę ludzkiego życia. Życie jest obrazem piękna. Życie przejawia piękno w ludzkim ciele. Piękno działa więc w istocie człowieka zarówno jako życie, jak i uczuciowość. Piękno działa na styku duchowości i cielesności. Piękno kształtuje naszą zmysłowość i funkcje życiowe. Piękno nadaje osobowy kształt zarówno zmysłowości, jak i życiu ludzkiemu. Wydaje się, że piękno działa najpierw jako życie. I to życie kształtuje zarówno cielesność, jak i zmysłowość. Życie bowiem działa mocą piękna. To życie przyczynowane przez piękno kształtuje cielesność i zmysłowość.

W kobiecie dominuje piękno i dobro. To piękno i dobro kształtują osobowość kobiety. To piękno i dobro sprawiają, że osoba ludzka staje się kobietą. Kobiecość nie jest więc skutkiem rozwoju biologicznego, ani wychowania kulturowego, jak się dziś sugeruje. Kobiecość jest przejawem osobowej aktywności istnienia. Kobiecość jest wyrazem aktywności własności transcendentalnych piękna i dobra. Piękno i dobro mają przemożną moc działania. Piękno posiada moc sprawiania życia i uczuć. Piękno kształtuje ludzką uczuciowość. Bez udziału piękna ludzka zmysłowość i uczuciowość byłyby jedynie skutkiem oddziaływań 
naturalnych. Bez udziału piękna człowiek byłby tylko zwykłym zwierzęciem. Mógłby odczuwać tylko tyle, co zwierzęta. Mógłby odczuwać tylko przyjemności i przykrości cielesne. A przecież człowiek odczuwa tak wiele.

Zwłaszcza kobieta przeżywa i odczuwa tak wiele. Kobieta przeżywa wszystko jako piękno i dobro. Cały świat odczuwa jako piękny i przeżywa jako dobry. Można powiedzieć, że kobieta jest kapłanką piękna. Kobieta służy pięknu i życiu. Dlatego kobieta powinna poświęcić się służbie pięknu i życiu. Powinna żyć dla piękna i dla życia. Kobieta powinna odnaleźć piękno i życie w sobie samej. Musi poczuć wspaniałą moc piękna i pięknego życia. Kobieta musi doświadczyć upodobania piękna. Musi się poddać upodobaniu piękna.

Ale do takiego doświadczenia piękna potrzebny jest kontakt z Bogiem jako źródłem wszelkiego piękna. Bóg jest źródłem i przyczyną osobowego piękna. W Bogu piękno stanowi Bożą Chwałę. Boskie Piękno objawia się jako Chwała Boża. Boskie Piękno działa przy stworzeniu człowieka nadając ludzkiemu istnieniu transcendentalną własność piękna. To od Boga ludzki byt otrzymuje osobowe własności, które decydują o charakterze istoty. Dlatego powiemy, że ludzkie piękno (piękno osobowe) pochodzi od Boga. Osobowe piękno człowieka istnieje i działa pod wpływem Boga. Jeśli więc chcemy doświadczyć piękna, musimy najpierw otworzyć się na Boga.

Człowiek powinien odnaleźć piękno najpierw w sobie. Jednak do tego konieczne jest otwarcie się na Boga. To Bóg w nas działa poprzez osobowe piękno. To Boża łaska wywołuje w nas aktywność osobowego piękna. Dopiero wtedy pojawia się w nas upodobanie jako bezpośrednie oddziaływanie piękna. Upodobanie piękna ożywia naszą cielesność i zmysłowość. Upodobanie piękna ożywia ciało i uczucia. Wówczas wzmaga się w nas życie oraz rodzi się uczucie radości. Piękno wywołuje w nas podniecenie, które obejmuje uczucia i ciało. Doznając piękna czujemy się pobudzeni i podnieceni. Nasze uczucia rozpalają się ogniem podniecenia. Przeżywamy także wzmożenie naszego życia. Siły życiowe zaczynają działać, cielesność się rozpala. Wszystko jest gotowe do daru nowego życia. Ogarnia nas uczucie radości, euforii i spełnienia. Tak działa piękno. Musimy się nauczyć właściwie przeżywać piękno.

Kobieta jest stworzona do życia i piękna. Kobieta jest powołana do przeżywania piękna. Kobieta jest czuła i otwarta na piękno otaczającego świata. Kobieta czuje piękno. Kobieta czuje i doświadcza piękna życia. Ona bezpośrednio doświadcza i czuje narodziny nowego życia.

Osobowe piękno człowieka przemawia poprzez kobietę. Życie kobiety i cała kobiecość jest obrazem piękna. Dlatego mówimy, że kobiety są piękne. Kobiety są piękne wewnętrznym pięknem. Chodzi o piękno osobowe. Kobiety muszą zrozumieć, że piękno jest naprawdę zawarte w nich samych. Kobiety muszą pozwolić ujawnić się temu pięknu. Muszą pozwolić ujawnić się pięknu osobowemu. Kobieta jest piękna sama w sobie, nie potrzebuje ozdób i dodatków. Nic tak czło- 
wieka nie upiększa jak własna osoba. Osoba kobiety wyraża się poprzez piękno. Czytamy o tym w Pieśni nad pieśniami $(1,15)$ : - „O, jak piękna jesteś, przyjaciółko moja, jak piękna". Ale dostrzegali to tylko mistycy - św. Bernard czy św. Bonawentura.

Kobieta musi dziś odkryć w sobie prawdziwe piękno. Kobieta musi odkryć w sobie piękno życia. Wciąż dają tego świadectwo nowe matki. Matka najlepiej czuje piękno nowego życia. Tutaj trzeba poddać się uczuciom. Nie można poszukiwać racjonalizacji i rozumowych argumentów. Nasze myślenie zbyt często wyprowadza nas na manowce. Wszelkie zbrodnie przeciwko życiu rodzą się $\mathrm{z}$ błędnego myślenia.

Kobieta musi się poddać własnej czułości i serdeczności. Zwracając się ku nowemu życiu kobieta powinna się kierować czułością i serdecznością. Kobieta musi tę czułość ukazać mężczyźnie. Musi przekazać mu tę czułość. Musi nią zarazić mężczyznę i przekonać go do życia. Nie jest to łatwe. Pomocą i wsparciem jest tutaj łaska Boża i miłość małżeńska. Nowe życie wymaga miłości i oddania, czułości i serdeczności. Ale nowe życie daje nam w zamian radość i nadzieję.

Kobieta jest ukształtowana przez piękno. Ale kobieta zarazem zmierza do piękna. Początkiem i kresem jest tu osobowe piękno. Początkiem jest dar życia i kresem jest dar życia. Spełnieniem kobiecości i jej piękna jest najwspanialszy dar życia. Dopiero wówczas piękno kobiety jaśnieje największym blaskiem. Ten blask piękna jest najczęściej widoczny na twarzy każdej matki. Ten blask piękna jest przedstawiony na ikonach Matki Bożej. Matka Boża jest najdoskonalszym odbiciem i obrazem Boskiego Piękna, czyli Chwały Bożej.

\section{Kobieta i życie}

Każda kobieta pragnie żyć pełnią życia. Pragnie spelnić swoje życie w najwyższym stopniu. Trzeba zatem zapytać, gdzie możemy dziś odnaleźć pełnię życia? Gdzie powinniśmy szukać tego życia? Jak możemy spełnić nasze życie?

Życie jest samą realnością człowieka. Życie jest źródłem tej realności. Dlatego życia nie znajdziemy dookoła siebie, w świecie rzeczy. Dziś nie znajdziemy życia także w kulturze. Życie możemy odnaleźć tylko w człowieku. Najpierw w sobie, a potem także $\mathrm{w}$ drugim człowieku. Życie możemy odnaleźć właśnie w człowieku, bo życie jest realnością człowieka. Aby poczuć i spotkać życie, musimy sięgnąć do realności człowieka. Musimy sięgnąć do jego wnętrza, do tego, co stanowi „głębię", czyli do istnienia.

Dziś kobiecie nie jest łatwo sięgnąć w głąb siebie. Wszystkie reklamy i czasopisma skłaniają ją do dbałości o to, co zewnętrzne (o wygląd), wołając, że wtedy na pewno stanie się sobą. Oczywiście kobieta potrzebuje zewnętrznego piękna, ale przede wszystkim potrzebuje piękna wewnętrznego. Wewnętrznym pięknem 
kobiety jest życie. Życie niesie ze sobą realne piękno. Życie jest pierwszym obrazem piękna. To właśnie życie decyduje o wewnętrznym i zewnętrznym pięknie. Życie obdarza kobietę prawdziwym pięknem.

Aby być piękną, kobieta potrzebuje również radości życia. Prawdziwą radość daje człowiekowi przeżycie realnego i osobowego piękna. Realne piękno jest zawarte w istnieniu (egzystencji) człowieka. Natomiast w istocie piękno przejawia się jako życie. Życie jest obrazem osobowego i egzystencjalnego piękna. Piękno życia oddziałuje na nasze uczucia. Upodobanie piękna stanowi pierwotną pobudkę dla naszej uczuciowości. Bez upodobania piękna nie rozwinie się w pełni ludzka uczuciowość. Wówczas uczucia stają się tylko zwykłymi doznaniami cielesnymi - doznaniami przyjemności lub przykrości. Ale takie doznania wywołują jedynie zmienność uczuć (huśtawkę uczuć, jak mówimy). Aby osiągnąć trwałość przeżycia radości i nadziei, musimy doświadczyć oddziaływania samego piękna i jego obrazu w postaci życia. Bez doświadczenia życia i piękna kobieca uczuciowość będzie rozchwiana i zmienna, przypadkowa i nieprzewidywalna. Kobiecemu życiu i uczuciowości potrzebna jest trwałość i nadzieja, potrzebna jest prawdziwa radość i ciepło serca.

Jeśli kobieta zamierza odzyskać swoje uczucia, jeśli zamierza odzyskać prawdziwą radość życia, to musi poczuć moc życia i jego piękno, musi się poddać oddziaływaniu wewnętrznego piękna, musi przyjąć i oddać się życiu, musi się stać służebnicą życia. Jest to bardzo trudne wyzwanie. Trzeba bowiem iść na przekór modzie. Trzeba zdobyć siłę, aby przeciwstawić się modnym trendom i całej kulturze użycia i przyjemności. Trzeba umieć powiedzieć „nie” wszystkim wymyślonym teoriom i poglądom. Trzeba porzucić zgubne oceny i wartości wymyślone przez ludzi. Trzeba natomiast wrócić do źródła, do korzeni. Trzeba pokochać życie. Trzeba pokochać realne życie zawarte w człowieku. Trzeba chcieć nadać życiu charakter osobowy, a nie traktować je jako fakt biologiczny. Trzeba przywrócić życiu osobowe piękno. Trzeba pokochać życie jako obraz osobowego piękna. Trzeba doświadczyć w sobie osobowego piękna.

Kobieta musi w sobie odnaleźć osobowe piękno. Musi doświadczyć tego piękna w sobie i musi ukazać je mężczyźnie. Kobieta powinna objawić mężczyźnie piękno życia, a wówczas uratuje naszą kulturę przed zagładą. Z kolei mężczyzna musi się nauczyć wielbić kobiece piękno. Ale takie uwielbienie dla piękna powinno się łączyć z upodobaniem życia. Osobowe piękno kobiece jest pięknem życia. Piękno kobiety łączy się z życiem. Zachwycając się kobiecym pięknem mężczyzna musi dostrzec dar życia. Zachwycając się pięknem kobiety mężczyzna powinien zachwycić się jednocześnie pięknem samego życia. Ukazując kobiecie swój zachwyt mężczyzna podkreśla i docenia rangę życia. Mężczyzna musi pokazać swój zachwyt i uwielbienie dla życia, aby kobieta mogła go wybrać na męża. Dopóki mężczyzna nie zachwyci się życiem, dopóty nie jest przygotowany do roli męża i ojca. 
Zwykle ten zachwyt dla życia przychodzi już po narodzinach dziecka. Ale ten zachwyt i fascynacja powinny być podstawą wspólnoty życia. Ta fascynacja powinna być również podstawą miłości oblubieńczej. Zasadniczym impulsem dla miłości jest afirmacja osobowego dobra. Ale gdy nie rozpoznajemy jeszcze takiego dobra, to pierwszym impulsem może być właśnie fascynacja pięknem i życiem. Ta fascynacja prowadzi nas bowiem prostą drogą ku osobie. Jeżeli mamy problem $z$ doświadczeniem życia i zachwytem dla niego, to możemy zagubić swoje osobowe życie.

Mężczyzna powinien zachwycić się pięknem i życiem kobiety. Dopiero wtedy zdoła pokochać źycie, a potem zdoła odkryć i pokochać osobowe dobro, i wreszcie zdoła dotrzeć do osobowej prawdy. Dopiero wtedy mężczyzna odkryje godność człowieka jako osoby. Wtedy zrozumie, że Chwałą Bożą jest człowiek żyjący (św. Ireneusz), że jest Nią realna osoba stająca obok niego.

Życia dotyczy fascynacja (podniecenie) i radość. Jeśli małżonkowie pragną połączyć się dla życia i związać z życiem, to muszą osiągnąć stan fascynacji życiem. Muszą osiągnąć stan najwyższego podniecenia. Muszą osiągnąć wzajemną fascynację życiem drugiej osoby. Związek małżeński powinien być oparty na fascynacji i uwielbieniu życia.

To kobieta ma za zadanie przygotować mężczyznę i nauczyć go cenić życie ponad wszystko. Mężczyzna nie jest tak czuły i otwarty na życie jak kobieta. Kobieta jest strażniczką i służebnicą życia. To kobieta wie wszystko o życiu. Kobieta jest otwarta i czuła na życie. Ona czuje każde poruszenie i drgnienie życia (nowego życia). Kobieta czuje w sobie dar życia i staje się dla niego ochroną. Rolą kobiety jest chronić życie i wydać je na świat. Dawna formuła, że kobieta jest strażniczką domowego ogniska, symbolizuje ochronę życia w rodzinie.

Właściwą drogą kobiety jest odkrycie w sobie piękna osobowego - piękna życia. Zadaniem kobiety jest ukazać światu blask piękna. Tym blaskiem piękna jest nowe życie, które kobieta przyjmuje w swym łonie. Jaśniejąc takim blaskiem piękna i życia, kobieta objawia światu niezachwianą prawdę, że życie jest darem. W swoim powołaniu kobieta ma do przekazania prawdę o życiu. Ukazuje to życie w świetle osobowym, ukazuje dar życia. Dar życia jest świadectwem osobowej troski o życie. Jest świadectwem osobowej troski Boga i człowieka. Bóg przekazał ludziom dar życia. Natomiast ludzie (kobieta i mężczyzna) muszą ten dar przyjąć, chronić i rozwijać. $Z$ racji osobowego powołania kobiecości, kobieta jest najbliżej życia, ona ogarnia i obejmuje nowe życie swoim życiem, chroni je swoim ciałem.

Kobiecość to oddanie życia dla życia. Kobiecość to służba życiu. Dlatego to kobieta najlepiej odczuwa życie. To kobieta w pełni przeżywa życie. To ona najlepiej zna życie. Mężczyzna może się tylko uczyć od kobiety. Może słuchać, co o życiu mówi kobieta. Może nawet posłuchać samego życia, które rozwija się w łonie kobiety. Dlatego jeśli mężczyzna chce poznać życie, musi być razem z kobietą, musi czuwać przy niej, musi troszczyć się o nią i o życie w jej łonie. 
Mężczyzna musi pokochać kobietę, aby zdołał pokochać życie. Bez udziału kobiety mężczyzna nie pozna życia, nie zdoła spotkać się z życiem i poczuć jego ciepła i radości. Bez udziału kobiety mężczyzna nie zdoła osiągnąć radości życia, nie będzie mógł nacieszyć się życiem. Bez kobiety mężczyzna może tylko myśleć o życiu i wyobrażać sobie niestworzone rzeczy na temat życia. Ale dopóki nie spotka prawdziwej realności życia w kobiecie, dopóty nie będzie w stanie odkryć sensu życia, także własnego życia. Zdarza się, że mężczyzna zamienia realność życia na użycie i przyjemność, ale wtedy zaczyna żyć jedynie pozorami życia.

Dlatego dopiero dzięki spotkaniu kobiety z mężczyzną, dzięki połączeniu jej życia $z$ jego życiem, człowiek jest w stanie zrozumieć życie. Dopiero wtedy możemy zrozumieć wspaniały dar życia. Odkrywamy, że życie jest darem. Że życie potrzebuje miłości. Że nie jest tylko jakimś przypadkowym biologicznym faktem, ale jest wydarzeniem (wy-darz-eniem) osobowym i osobowym darem. Dopiero wtedy odkryjemy w człowieku osobę i jej godność, odkryjemy osobowe działanie jako dar życia i miłości. Odkryjemy na koniec osobową wspólnotę - wspólnotę życia i miłości - czyli rodzinę.

\section{Kobieta i uczucia}

Uczucia powstają w człowieku na kanwie piękna (na mocy piękna). Piękno jako własność transcendentalna jest zawarte $w$ istnieniu. Ta własność piękna bierze udział $w$ powstawaniu istoty człowieka. Piękno bierze bezpośredni udział $\mathrm{w}$ tworzeniu sfery uczuciowej (uczuciowości człowieka). Ludzkie uczucia są wytworem piękna. Powstają pod wpływem oddziaływania piękna. Piękno ukształtowało ludzką uczuciowość i zmysłowość, a poprzez nie także cielesność człowieka. Ludzkie ciało jest piękne. Ludzkie ciało jest ożywiane przez piękno. Wydaje się zatem, że to właśnie piękno obdarza człowieka życiem. Piękno ożywia ludzki byt. Piękno przyczynuje życie. Piękno nadaje życie ludzkiemu ciału. Ludzkie ciało zostało stworzone jako ożywione.

Zmysłowość (sensibilitas), czyli uczucia, łączą to, co duchowe z cielesnością. To zmysłowość ożywia ciało. Zmysłowość wyznacza funkcje życiowe, czyli określa to, co stanowi życie (wzrost, odżywianie i rozrodczość, czyli płodność). Piękno działa w zmysłowości (w uczuciach) odbijając się w ciele i życiu. Zmysłowość i życie stanowią przejaw piękna w zakresie cielesności. Ciało człowieka jest piękne dzięki życiu i uczuciom. Życie i uczucia stanowią bezpośrednie przejawy piękna.

Kobieta przejawia się jako piękno. Kobieta przejawia się jako życie i zmysłowość (uczucia). W kobiecie dominuje piękno. Kobiecość jest domeną piękna. Dlatego mówimy, że kobiety są piękne. Można więc przyjąć, że osoba kobiety (osobowość kobiety lub kobiecość) otrzymała przewagę w zakresie życia i uczuć. Kobieta żyje i wyraża się poprzez uczucia. 
Bóg stworzył kobietę z żebra Adama. Musiał więc coś zabrać człowiekowi, żeby dać to kobiecie. Dlatego mężczyzna został pozbawiony czegoś na rzecz kobiety, zaś kobieta otrzymała cząstkę Adama (człowieka - Adama Kadmona). Dlatego mężczyzna i kobieta dopełniają się i uzupełniają w osobowej wspólnocie. Kobieta otrzymała do dyspozycji życie i uczucia. Mężczyzna pozostał ze swoim rozumem ( $z$ dominacją rozumu). Kobieta i mężczyzna najlepiej mogą funkcjonować we wspólnocie. Połączenie tych dwóch osobowości - kobiecości i męskości - daje doskonałą osobę-wspólnotę. Z połączenia oraz z wzajemnego oddania siebie powstaje pełnia osobowego bytowania - wspólnota jako osobowa jedność, która może się rozwijać, czyli zrodzić nowych ludzi.

Kobieca osobowość (osoba kobiety) jest zdominowana przez piękno i dobro. Dlatego kobieca osobowość przejawia się pod postacią „serca”. U kobiety dominuje serce (serdeczność). Kobiece serce stanowi połączenie woli i uczuć. Kobieta bardziej czuje (odczuwa i przeczuwa) niż rozumie. Dlatego mówi się o kobiecej intuicji. Jest to intuicja serca, a nie rozumu. Kobiece serce jest czułe i otwarte. Jest czułe i otwarte na piękno i dobro, jest czułe i otwarte na życie. Kobiece serce odczuwa i przeżywa życie poprzez kategorie piękna i dobra. Kobieta wszystko doświadcza w kategoriach piękna i dobra. Świat jest dla niej piękny i dobry. Takie doświadczenie jest potocznie nazywane romantycznym. Mówimy, że kobiety są romantyczne. One po prostu odbierają wszystko jako piękne i dobre.

Piękno oddziałuje na uczucia człowieka, dobro zaś działa na naszą wolę. Wola współpracuje bezpośrednio z uczuciowością (z uczuciami). Piękno wywołuje upodobanie. Upodobanie jest bezpośrednim oddziaływaniem piękna na nasze uczucia. Upodobanie stanowi doświadczenie piękna, stanowi odebranie jego oddziaływania. Właściwie upodobanie stanowi poddanie się oddziaływaniu piękna, stanowi samo przyjęcie piękna w naszej uczuciowości. Upodobanie piękna działa już na nasze uczucia. Upodobanie piękna wywołuje w człowieku pierwsze uczucia. Upodobanie piękna wywołuje radość i podniecenie. Możemy w tym przypadku mówić o fascynacji. Piękno jest fascynujące. Piękno jest podniecające. Piękno cieszy nas i raduje. Taka fascynacja pięknem wywołuje pierwsze uczucie (pierwotne uczucie).

Aby nasza uczuciowość mogła prawidłowo funkcjonować, musi zostać pobudzona i rozbudzona przez upodobanie piękna. Wtedy pojawia się przeżycie fascynacji - czyli uczucie radości i podniecenia. Bez przeżycia fascynacji nasza uczuciowość może pozostać niespełniona. Mówimy wtedy o oziębłości uczuciowej. Bez fascynacji pięknem nasze uczucia pozostaną zimne i martwe.

Kobieta w sposób naturalny doświadcza tej fascynacji pięknem. Tej fascynacji powinna $z$ kolei nauczyć mężczyznę. Kobieta powinna zachwycić mężczyznę swoim pięknem. Powinna ukazać mu zachwycające piękno świata. Kobieta musi zafascynować mężczyznę, to znaczy doprowadzić go do fascynacji realnym pięknem. Musi to być prawdziwa fascynacja, czyli fascynacja realnym pięknem 
rzeczywistości. To realne piękno najpierw przejawia się w ludzkim życiu. Życie jest obrazem piękna. A dopiero dalej piękno życia przejawia się w ludzkim ciele. Mężczyzna najpierw zachwyca się pięknem ciała. Kobieta powinna rozwinąć tę fascynację cielesnością i przenieść ją na samo życie. Dopiero gdy fascynacja i zachwyt obejmą piękno życia i ciała, można mówić o pełnym przeżyciu piękna. Dopiero fascynacja życiem prowadzi do wzajemnego przeżywania piękna. Dopiero wtedy można mówić o uczuciowym spełnieniu kobiety i mężczyzny. Wszystko inne jest tylko przeżyciem chwilowej przyjemności, jest doznaniem cielesnej przyjemności - jak się dziś mówi - jest tylko chemią. Prawdziwa radość i nadzieja rodzi się z przeżycia piękna zawartego w życiu.

Przeżycie piękna związanego z życiem budzi w nas radość i nadzieję. Dlatego powiemy, że prawdziwa radość jest związana z pięknem życia (zwłaszcza z pięknem rodzącego się życia). Jeżeli chcemy przeżyć prawdziwą radość i nadzieję, musimy zachwycić się pięknem ludzkiego życia, musimy dostrzec to piękno i znaleźć w nim upodobanie. Bez doświadczenia piękna, które niesie ze sobą życie, nie doznamy nigdy prawdziwej radości. Tylko taka radość jest radością życia. Jedynie człowiek doświadczający piękna życia może się cieszyć prawdziwą radością życia. Życie jest piękne! Często tak wołamy i nie jest to tylko poetycka euforia, lecz realna prawda. Życie jest bowiem związane z transcendentalną własnością piękna. To ona kształtuje ludzkie życie. To ona nadaje mu osobowy kształt, to znaczy czyni to życie przejawem i obrazem osoby ludzkiej.

Ten, kto doświadcza samego piękna, może odczuwać prawdziwą radość i nadzieję. Możemy więc przyjąć, że to kobieta jest w stanie przynieść światu radość i nadzieję. To ona daje radość i nadzieję mężczyźnie, aby mógł razem z nią przeżywać piękno życia. To kobieta niesie radość i nadzieję, jaka łączy się z darem nowego życia.

Uczucia nie dzieją się gdzieś na marginesie naszego człowieczeństwa. One są obrazem i wyrazem naszej osoby. Są bowiem kształtowane przez piękno, które jest przejawem samego istnienia człowieka (przejawem ludzkiej egzystencji). Uczucia wyrażają więc to, co w człowieku najgłębsze - czyli osobowe. I właśnie jako takie nadają ludzkiej cielesności najgłębszy sens. Uczucia są powiązane z pięknem i życiem. Powinny zatem przejawiać upodobanie piękna i radość życia. Dopiero wtedy nabierają głębokiego sensu. I dopiero wówczas są w stanie połączyć głęboką więzią uczuciową dwoje ludzi. Uczucia powinny lączyć ludzi. Uczucia łączą przede wszystkim kobietę i mężczyznę. Uczucia łączą także rodziców i dzieci.

Uczucia nie są jedynie doznaniami przyjemności cielesnej. Uczucia są przede wszystkim przeżyciami piękna i radości życia. Tylko dzięki temu uczucia zostają powiązane ze sferą osobową, czyli z osobowym pięknem i życiem. Jeżeli uczucia czerpią siłę i moc od życia i piękna, wówczas mogą wspierać ludzkie działania - te działania, które są osobowe i moralne. Bez tego wsparcia ze strony piękna, 
ludzkie uczucia pozostaną jedynie huśtawką doznań i namiętności, które będą targały naszym życiem, naszym rozumem, naszą duszą. Ludzkie uczucia nie mogą się ślizgać po powierzchni ciała. One muszą wypływać z samego wnętrza naszej osoby, naszej egzystencji. Uczucia mają objawiać naszą osobę, a nie doznania cielesności. Dopiero wówczas osoba i dusza zdoła zapanować nad ciałem, a ciało i zmysłowość staną się obrazem duszy i osoby.

Kobieta jest źródłem takiej głębokiej uczuciowości. Osoba kobiety przejawia się i działa poprzez uczucia. Kobiecość obdarza nas fascynującą uczuciowością. Kobieta roznosi w świecie i rozdaje upodobanie piękna i radość życia. Takie uczucia odnajdziemy w każdej kobiecie. Trzeba tylko pozwolić im się ujawnić. Kobiety nie mogą ukrywać swoich uczuć. Kobieta powinna obdarzyć nimi mężczyznę. Musi przekonać go do upodobania piękna i do radości życia. Tylko wtedy kobieta zdoła pociągnąć za sobą mężczyznę. Tylko wtedy zdoła przekonać go do swojej osoby. Mężczyzna nie szuka w kobiecie wiedzy i sukcesu. On szuka w niej ciepła i radości, fascynacji pięknem i dobrem, szuka nadziei na nowe życie. Mężczyzna szuka w kobiecie tego, czego brakuje jemu samemu. Szuka tego, czego potrzebuje we wspólnym życiu.

Jeśli kobieta tego nie zrozumie, jeśli będzie się starała dorównać mężczyźnie lub go prześcignąć ( $w$ wymyślonym wyścigu do sukcesu), to zagubi swoją osobowość (osobę), zagubi swoją kobiecość i stanie się nijaka. Osoba nie jest samowystarczalna. Osoba żyje dla drugiej osoby. Osoba realizuje się we wspólnocie. Jeśli kobieta uzna, że jest samowystarczalna, to zginie, zatraci swoją osobę i osobowość. Podobne zagubienie grozi mężczyźnie, jeśli uzna, że jest samowystarczalny. Marzenie o samowystarczalności prowadzi do zaniku osoby w człowieku. Osoba rodzi się bowiem i ujawnia we wzajemnych relacjach. Osoba rodzi się i ożywa jedynie w kontakcie $z$ drugą osobą. Kobieta ożywa w relacji z mężczyzną, a mężczyzna w relacji z kobietę. Kobieta i mężczyzna ożywają naprawdę we wzajemnym oddaniu. Dać siebie, to spełnić swoją osobę. Dopiero wzajemne oddanie jest działaniem prawdziwie osobowym.

\section{Kobieta i ciało}

Kobiece ciało zostało pośrednio ukształtowane przez piękno. Kobiece ciało jest piękne. Kobiece ciało służy życiu i daje życie. Ciało człowieka jest bezpośrednio ukształtowane przez życie. $Z$ kolei życie człowieka jest przyczynowane przez własność piękna. W ciele odbija się zatem życie i piękno. Życie jest pięknem ciała. To życie stanowi o pięknie ciała, a nie właściwości cielesne. Piękne jest żywe ciała. Każde żywe ciało przynosi ze sobą piękno. Każde żywe ciało stanowi przejaw piękna. Ludzkie ciało zostało ukształtowane przez osobowe piękno. Ludzkie ciało jest wyjątkowe i szczególne. Ono służy osobie człowieka do życia. Osoba 
(byt osobowy) może się posługiwać tylko ludzkim ciałem. Może lepiej byłoby powiedzieć, że osoba przyobleka się właśnie w ludzkie ciało. Zarówno duchowość człowieka, jak i cielesność są przyczynowane przez własności osobowe zawarte w osobowym istnieniu. To K. Wojtyła pierwszy określił istnienie człowieka jako osobowe. Osobowe istnienie stanowi podmiot osobowy. Osobowa aktywność człowieka płynie $\mathrm{z}$ istnienia. Osobowe własności transcendentalne - prawda, dobro i piękno - przyczynują istotę człowieka. Piękno sprawia to, co łączy duszę z ciałem. Piękno sprawia życie i zmysłowość (zmysły i uczucia). Życie wpływa bezpośrednio na kształt naszej cielesności. Także zmysłowość kształtuje narządy cielesne. Za stronę materialną cielesności odpowiadają pozostałe własności transcendentalne - jedność, odrębność i realność (res). Dlatego uważamy, że ciało człowieka zostało sprawione przez piękno i życie. Materialność lub fizyczność ciała jest tylko dopełnieniem.

W kobiecym ciele widać oddziaływanie piękna i życia. Można powiedzieć, że to właśnie ciało kobiety objawia piękno i życie. Kobieca cielesność ukazuje nam moc sprawczą piękna, ukazuje także moc ożywczą życia. Ciało kobiety sprawione i ukształtowane przez piękno służy darowi życia. Ten dar życia, cała służba życiu są wpisane w kobiecą cielesność. Kobiece ciało jest pierwszym i najważniejszym środowiskiem rozwoju życia, a tym samym stawania się piękna. Piękno i życie staja się w kobiecym ciele. To ciało jest sanktuarium życia i piękna, To nie jest zasługą przyrody (natury), ani człowieka. Kobiece ciało jest skutkiem działania osobowego istnienia, które zostało stworzone przez Boga. Kobieca cielesność ma swoje miejsce w zamyśle Bożym, podobnie jak cielesność mężczyzny. Bóg stworzył człowieka. Mężczyzna i kobietą stworzył ich. Bóg dał osobowe istnienie zarówno mężczyźnie jak kobiecie. Bóg sprawil, że osoba ludzka powstaje konkretnie jako kobieta i mężczyzna. Dzięki temu osoba ludzka ma możliwość połączenia się we wspólnocie $z$ drugą osobą. Osoba ludzka została stworzona jako byt wspólnotowy i relacyjny - jako byt dla drugiego. Dlatego ludzka cielesność powstała, aby można było zrealizować związek wspólnotowy. Ciało mężczyzny i ciało kobiety dopełniają się, co umożliwia osiągnięcie połączenia. Ale pozwala także na zrodzenie nowego człowieka, który jest bytem duchowo-cielesnym, czyli potencjalna osobą. Dlatego w tworzeniu ludzkiej cielesności biorą udział osobowe własności transcendentalne. Dlatego ludzkie ciało jest kształtowane przez osobowe piękno.

Ciało kobiety jest szczególnym miejscem oddziaływania piękna, które splata się z życiem. Ciało kobiety jest środowiskiem rozwoju i wzrastania osobowego życia człowieka. Tu nie chodzi już o życie biologiczne (naturalne). W kobiecym ciele poczyna się i rodzi z niego realny człowiek - żywy i cielesny byt osobowy. Kobiece ciało jest miejscem rozwoju osobowego bytu. To nie jest tylko płód lub zarodek. To jest ludzka osoba, choć dostrzegalna tylko w swej cielesności. Ale czyż inne ludzkie osoby też nie postrzegamy poprzez ich cielesność? Dlatego cia- 
ło kobiety możemy nazwać sanktuarium, gdyż zamieszkuje w nim osoba (człowiek-osoba). Raz zamieszkał nawet Bóg (Osoba Boska - Syn Boży).

\section{Kobieta i płodność}

Nie sposób zrozumieć kobiety bez płodności, a płodności bez kobiety. Kobieta została bowiem stworzona i powołana do płodności. Płodność stanowi doskonałość życia. To życie daje nam płodność. Doskonałość kobiecego życia sprawia, że staje się ona płodna. Tą doskonałość życia przyczynuje piękno. Im silniej w kobiecie działa piękno (czyli transcendentalna własność piękna), tym doskonalsze staje się jej życie. A im doskonalsze jest to życie, tym silniejsza płodność. Płodność nie jest więc efektem działania sił biologicznych. Płodność ma bezpośredni związek z osobą kobiety. Dzieje się to za sprawą własności piękna i zdolności życia. To piękno przyczynuje w człowieku życie, zaś życie przejawia się w płodności. Życie jest obrazem piękna zawartym w ciele, zaś płodność jest pięknem, dobrem i prawdą życia. Życie ma przemożną siłę. Życie jest płodne. Życie jest płodnością. Płodność jest darem życia i piękna, a z kolei życie jest darem piękna i płodności.

Dlatego możemy powiedzieć, że płodność człowieka ma źródło w samej osobie ludzkiej (w ludzkiej egzystencji). To tam - w akcie stworzenia - zaczyna się cały metafizyczny proces rozwoju człowieka. Bóg stwarza istnienie człowieka wyposażając je we własności osobowe - prawdę, dobro i piękno. Te własności przyczynują i kształtują istotę człowieka. Prawda kształtuje rozum, dobro wolę, a piękno całą zmysłowość człowieka. Piękno przyczynuje uczucia, zmysły i życie. Życie jest obrazem i przejawem piękna w ciele. Życie jest pięknem ciała. Ludzkie ciało jest piękne dzięki życiu. To samo życie świadczy o pięknie ludzkiego ciała. Każde żywe ciało jest piękne, dobre i prawdziwe.

U kobiety życie dysponuje szczególną siłą i potęgą. Cała osoba kobiety wyraża się w sile i potędze życia. Kobiecość wyraża się w doskonałości życia. Kobiecość przejawia się w płodności. Kobiecość, która została ukształtowana przez piękno i życie, spełnia się w płodności. Kobieta została stworzona i powołana do płodności. Płodność jest wypełnieniem daru życia. Płodność jest służbą życiu. To piękno życia powołuje nas do płodności. Piękno wzywa nas do płodności. Piękno życia domaga się płodności. Bez płodności życie straciłoby swoje piękno. Ludzkie życie jest ograniczone, jest słabe i kruche, jest krótkie. Aby życie mogło ujawnić swoje piękno i swoją doskonałość, musi osiągnąć płodność. To płodność jako ciągłość życia jest spełnieniem doskonałości.

Kobieta została powołana do płodności. Kobieta została także powołana do przeżywania życia i płodności. Kobiece piękno przejawia się w rozwoju życia oraz w uczuciach. Kobieca uczuciowość jest dostosowana do przeżywania daru życia 
i płodności. Kobieta przeżywa realność jako piękno i dobro. Kobieta przeżywa własną realność poprzez uczucia radości i nadziei. Kobieta wspaniale odczuwa piękno życia. Kobieta przeżywa i odczuwa życie jako piękno. To cieszy i raduje jej uczucia. Tylko kobieta ma zdolność takiego pięknego i radosnego przeżywania życia. Uczuciowość stoi bowiem najbliżej życia. Uczucia najlepiej informują nas o życiu i jego rozwoju. Dlatego powiemy, że to kobieta najpełniej przeżywa życie i najwięcej „wie” o życiu. Kobieta zna życie najlepiej. Kobieta doświadcza i przeżywa bezpośrednio sam dar życia. Kobieta najpełniej przeżywa płodność. Kobieta doświadcza płodności jako daru życia.

To kobieta daje nowe życie. Kobieta niesie ten dar życia dla świata. Kobieta przynosi światu nowe życie. Jednocześnie kobieta doświadcza i przeżywa cały proces przyjęcia życia, jego rozwoju i wzrastania. Kobieta posiada więc niepodważalne doświadczenie życia. Kobieta przeżywa sam dar życia. Kobieta naprawdę odczuwa dar życia. Podsumowując powiemy, że to właśnie kobieta zna najlepiej ludzkie życia. Dlatego kobieta może najwięcej nauczyć nas o życiu. Kobieta powinna przekazać swoje doświadczenie mężczyźnie. Powinna nauczyć mężczyznę dostrzegania piękna życia. Kobieta powinna przekonać mężczyznę do płodności, która jest doskonałością życia.

Kobieta ma ważną misję służenia życiu. Służba i chronienie życia jest zadaniem kobiety. Istota i osoba kobiety (jej kobiecość) może się spełnić właśnie w służbie życiu. Najlepszą służbą życiu jest płodności i dalsze chronienie życia. Kobieta została powołana do chronienia życia. Kobiecość spełnia się w ochronie życia.

Kobiety muszą nauczyć się propagowania życia. Kobiety powinny walczyć o życie, gdyż jest to zarazem propagowanie własnej kobiecości. Nie ma kobiecości bez spełnienia życia. Nie ma kobiecości bez doświadczenia piękna życia. Nie ma kobiecości bez daru życia. Nie ma kobiecości bez służby życiu. Nie ma kobiecości bez płodności.

Płodność pozwala kobiecie pięknie przeżywać swoją kobiecość. Pozwala kobiecie przeżywać całą głębię życia. Pozwala jej poznać samo źródło życia, czyli Boga. „Wielbi dusza moja Pana, (...) gdyż wielkie rzeczy uczynił mi Wszechmogący". (Łk 1,46-49). Płodność pozwala kobiecie doświadczyć własnej osoby. Osoba kobiety przejawia się w życiu i darze życia. Kobieta jest Ewą, czyli dającą życie (Chawwa). Kobieta jest „matką wszystkich żyjących” (Rdz 3,20). Kobieta jest więc matką. Jako matka spełnia swoją kobiecość. Kobieca osoba wypełnia się zatem w darze życia, w płodności.

\section{Aby pokochać życie}

Człowiek nie potrafi już dzisiaj pięknie żyć. Ma tak wygórowane ambicje, że zapomniał o swojej naturze, a nawet o własnej osobie. Wydaje mu się, że 
sztuka i technika wyniosą ludzką naturę na niebotyczne szczyty. Można przyjąć, że współczesny człowiek nie potrafi już doświadczyć samego siebie (głębi swej egzystencji), gdyż nie dysponuje odpowiednimi narzędziami. Współczesny człowiek zapomniał o swojej realności, zapomniał kim jest. Człowiek boi się po prostu człowieka, boi się samego siebie, boi się drugiego człowieka. Boi się nawet Boga-człowieka. Człowiek nie wytrzymuje już sam ze sobą albo z innymi ludźmi. Człowiek zagubił swoją naturę, stracił z nią kontakt. To znaczy, że człowiekowi brak realności. Człowiek otoczył się kulturą (otoczył się tworami kultury). Zauważa już wokół siebie tylko wytwory i sztuczne rzeczy (artefakty). Nie widzi natomiast realności, nie widzi nawet samego siebie. Człowiek nie rozumie własnego życia.

Człowiek nudzi się sam ze sobą. Nie umie dostrzec w sobie niczego interesującego. Jeśli człowiek nie otrzyma impulsu z zewnątrz albo podniety ze strony artefaktów (obrazu, dźwięku, zabawki itp.), to nie potrafi być sam ze sobą lub $z$ drugim człowiekiem. W ten sposób zamykamy się w coraz bardziej sztucznym świecie. Nie potrafimy obejść się bez ekranu (telewizora, komputera lub komórki). Jeśli na ekranie nic się nie dzieje, to zaraz się nudzimy. Taką nudę próbujemy pokonać przy pomocy zabawy. Chcemy, żeby coś się przed nami i dla nas działo. Ostatecznie wystarczy, że mruga do nas jakiś ekran. Nasze widzenie świata ogranicza się wyłącznie do ekranu. Świat postrzegamy tylko na ekranie. Nawet człowiek to dla nas ktoś, kto pojawia się na ekranie. Straciliśmy z oczu bliźniego, który przechodzi obok nas, który żyje obok nas. Taki człowiek przestaje już być ważny. Ważne jest to, co pojawia się na ekranie. Chwalimy i podziwiamy tych, których widzimy na ekranie. Chcemy żyć tak jak na ekranie. Wtedy zaczynamy żyć światem pozorów (światem seriali, teleturniejów lub politycznego bełkotu z wiadomości). Wszystko to razem wzięte daje globalną paranoję. Zapytajmy: jak długo można żyć w świecie paranoi? To już chyba problem psychiatrów.

Dlaczego dziś kultura wytwarza taką paranoiczną wizję człowieka? Odpowiedź jest prosta. Kultura oderwała się zupełnie od natury i realności. Dopóki kultura zachowywała związek z naturą człowieka, dopóty wszystko było w porządku (w normie). Kultura służyła dawniej naturze i wspierała ją. Człowiek kulturalny nie musiał się kiedyś wstydzić swego człowieczeństwa. A dziś co się dzieje? Człowiek kulturalny żyje i działa wbrew swojej naturze. Chce nawet pozbyć się natury, zamienić ją na kulturę i modę. Czy jednak da się żyć samą modą lub kulturą? Czy można zaspokoić swe potrzeby samymi wytworami albo nawet obrazami z ekranu? Czy najemy się reklamami produktów spożywczych albo czy spełnimy się $\mathrm{w}$ wirtualnym świecie?

Człowiek musi powrócić do swojej realności i natury. Musi na nowo odzyskać realność swej natury. Człowiek musi na powrót sięgnąć do realności życia. Musi odzyskać samego siebie. Człowiek musi pokochać swoja naturę i swoje życie. Człowiek musi pokochać życie, aby odzyskać prawdę swojej natury. Realność 
człowieka jest ukryta w życiu. Tylko afirmacja życia pozwoli nam odkryć naszą realność. Życie niesie bowiem ze sobą całą realność człowieka. Życie przynosi ze sobą również to, co w człowieku jest osobowe. Ludzkie życie jest bowiem przejawem natury i osoby człowieka. To właśnie ludzkie życie może nas zaprowadzić w głąb człowieka, może pomóc zrozumieć naszą naturę i może też ukazać nam Stwórcę i Dawcę życia. Gdy poznamy i pokochamy życie, wtedy poznamy i pokochamy samego człowieka. Wtedy dopiero zdołamy pokochać samych siebie. Przestaniemy się bać siebie. Wreszcie gdy poznamy i pokochamy życie, wtedy poznamy i pokochamy Dawcę życia, czyli samego Boga.

Powinniśmy koniecznie odkryć w sobie własne życie. Musimy to życie pokochać. Musimy przeżyć głęboką fascynację życiem. Życie jest przecież fascynujące. To pozwoli nam odkryć piękno życia. Musimy szukać piękna w samym życiu. To właśnie życie niesie ze sobą osobowe piękno. Osobowe piękno staje się widoczne w naszym życiu. Dlatego piękna powinniśmy poszukiwać w ludzkim życiu. Powinniśmy je dostrzec $w$ tym, jak to życie przejawia się w ciele, jak wspaniale się rozwija i funkcjonuje, jak pięknie to życie się poczyna i rodzi, jak pięknie potrafi trwać i powracać do zdrowia.

Aby osiągnąć pełnię życia, człowiek musi upodobać sobie życie, musi poddać się jego sile, musi poddać się mocy piękna przejawiającego się w życiu. Dla człowieka nie ma większego piękna niż piękno życia. Oczywiście najdoskonalsze będzie piękno życia wiecznego. Człowiek powinien dążyć do osiągnięcia piękna życia wiecznego. Tylko wtedy osiągnie wieczne i trwałe piękno (Piękno Boskie). Bardzo często to, co bierzemy za miłość, jest tylko początkową fascynacją pięknem życia. Jest to fascynacja uczuciowa. Jest to jakieś przeżycie podniecenia i radości, nadziei. Te uczucia dotyczą piękna przejawiającego się w życiu. Na przykład podoba się nam cielesność wyrażająca życie. Takie upodobanie cielesności i związane z tym podniecenie często nazywamy zakochaniem się lub nawet miłością. Dlatego właśnie miłość najczęściej utożsamiamy z uczuciem podniecenia i radości. Ale to dopiero jest wstęp do prawdziwej i pełnej miłości. Jest to jedynie początek czegoś więcej. Oczywiście może to być początek prawdziwej miłości osobowej, czyli małżeńskiej.

Aby podążać ku miłości, powinniśmy najpierw przeżyć autentyczną fascynację pięknem życia i ciała. Musimy przeżyć ten wspaniały dar życia. Musimy przyjąć dar życia, aby móc oddać siebie drugiej osobie. Musimy przyjąć dar życia, abyśmy sami mogli działać na sposób daru - daru miłości. Jeśli nie przyjmiemy daru życia, to nie będziemy zdolni do daru miłości.

W dzisiejszej kulturze brakuje nam życia i miłości. Brakuje nam fascynacji życiem i poszanowania jego świętości. Brakuje również daru miłości i pełnej afirmacji drugiego człowieka. Brak nam chęci oddania się i służenia drugiemu człowiekowi. Chcemy wybierać tylko coś dla siebie. Chcemy posiadać wiele różnych rzeczy albo posiąść, czyli poddać sobie, wielu różnych ludzi. Nie chcemy 
jednak niczego dawać $\mathrm{z}$ siebie i od siebie. Boimy się oddać siebie komuś innemu. Boimy się poświęcenia, bo to już zahacza o coś świętego. To wszystko prowadzi do kryzysu - do kryzysu człowieczeństwa i kryzysu rodziny. Dlatego mamy kryzys rodziny, która jest wspólnotą życia i miłości.

Jeżeli chcemy pokochać życie, musimy dostrzec jego piękno. Musimy zobaczyć piękno, które przejawia się w człowieku jako życie i jako zmysłowość związana $\mathrm{z} \dot{z}$ yciem.

Piękno wywołuje upodobanie. Upodobanie jest związane z potrzebą oglądania. Pragniemy oglądać piękne rzeczy. Piękne rzeczy cieszą nasz wzrok. Piękne dźwięki cieszą nasze uszy. Mówi o tym Tomaszowa definicja piękna - Pulchra sunt, quae visa placent. Piękno cieszy i raduje. Piękno cieszy i raduje nasze zmysły i nasze uczucia. Upodobanie daje zadowolenie naszym zmysłom i podniecenie naszym uczuciom. To piękno, niosąc ze sobą upodobanie, zaspokaja i zadowala naszą zmysłowość. Upodobanie stanowi bezpośrednie oddziaływanie piękna na sferę zmysłowości. Piękno podoba się zmysłom. W ten sposób piękno uaktywnia zmysły i uczucia. Wówczas zmysły i uczucia upodobniają się do piękna i pięknych rzeczy. Można powiedzieć, że pod wpływem oddziaływania piękna zmysły upodobniają się do pięknych barw i obrazów, dźwięków i melodii. Natomiast uczucia osiągają wyższy poziom aktywności, jakim jest podniecenie i fascynacja. Piękno stanowi podnietę dla uczuć. Piękno jest podniecające. Piękno podnieca nasze uczucia, czyli je rozpala.

Podniecenie uczuć może pobudzać działanie woli i rozumu. Ale może też zaciemniać to działanie. A to znaczy, że musi być coś, co będzie koordynować działania tych władz - rozumu, woli i uczuć. Kontemplacja prawdy, wezwanie dobra, czyli sumienie, oraz upodobanie piękna - to wszystko musi się spotkać w jednym miejscu i zostać ogarnięte przez jedną zdolność. Tą zdolnością jest mądrość. Mądrość powinna ogarniać i dotyczyć całego działania człowieka. Mądrość musi ogarniać i koordynować wszystkie działania - zarówno rozumu, jak woli i uczuć. Ale mądrość obejmuje same podstawowe zasady tych władz. Mądrość łączy bowiem i jednoczy w sobie prawdę, dobro i piękno. Mądrość obejmuje te zasady, łączy i identyfikuje jako własności występujące w człowieku. W ten sposób mądrość dostrzega, że wszystkie trzy własności są zawarte w człowieku i umiejscowione w osobie człowieka. Mądrość łączy je w całość, którą określamy mianem godności człowieka. Dzięki temu mądrość identyfikuje godność człowieka, gdyż rozpoznaje, że te trzy własności są zawarte w człowieku i łączą się w szczególną rangę ludzkiej osoby i egzystencji. Mądrość dostrzega, że godność osoby opiera się na prawdzie, dobru i pięknie. Osobową godność odkrywamy więc dopiero na poziomie mądrości. Bez mądrości postępujemy w sposób rozumny, ale z pewnością nie osobowy. Bez mądrości nie jesteśmy w stanie poznać godności, a bez znajomości godności nie będziemy mogli działać w sposób moralny i osobowy. Trzeba więc powrócić do poznania mądrościowego. Postulował to papież Jan Paweł II w encyklice Fides et ratio. 
Dopiero mądrość ogarnia i integruje (czyli scala) wszystkie trzy własności osobowe. Mądrość odkrywa więc godność, która łączy w sobie prawdę, dobro i piękno. Dopiero gdy zidentyfikujemy godność, gdy ją poznamy i odkryjemy, dopiero wtedy możemy ją uznać za cel naszego działania. Dopiero wtedy możemy doświadczyć powinności wobec godności człowieka, a wreszcie zwrócić się do niej z akceptacją, afirmacją i fascynacją. Dzięki temu poszczególne własności osobowe zostają zebrane w osobową godność i podmiotowość osoby. I wówczas poszczególne władze mogą się odnosić już do samej osoby ludzkiej. Wtedy rozum poznaje i akceptuje (uznaje) osobę. Wola pragnie i afirmuje (kocha) osobę człowieka. Nawet uczucia przeżywają zachwyt i fascynację drugą osobą. Dopiero wtedy możemy powiedzieć, że doświadczyliśmy w pełni człowieka, gdyż nasze władze osiągają trwałość i doskonałość działania.

Osobowe działanie polega na dawaniu, a nie na wyborze. Pamiętajmy, że tylko w bezinteresownym darze osiągamy osobowy poziom naszej egzystencji. Dawanie jest aktem osoby. Jest właśnie tym działaniem, które osiąga bezinteresowność. Tylko osoba działa w sposób bezinteresowny. Papież Jan Paweł II pokazywał nam, że tak właśnie kocha nas Bóg. Bóg jest Miłością. Bóg kocha nas bezinteresownie. Bóg kocha nas w sposób osobowy. Kocha nas nie dla siebie, ale dla nas samych, to znaczy kocha nas ze względu na nas samych. Ale Bóg ma również moc obdarzyć nas taką miłością. Jeśli przyjmiemy Bożą miłość, wtedy zdołamy pokochać siebie i innych ludzi. Wtedy zdołamy zachwycić się życiem i jego pięknem. Wtedy pokochamy życie naprawdę. Wtedy będziemy żyli na chwałę Bożą.

\section{Bibliografia}

JAN Pawet II, Encyklika Fides et ratio.

JAN PAWEe II, Adhortacja apostolska Familiaris consortio.

JAN PaWee II, List do Kobiet Mulieris dignitatem.

JAN PAWEe II, Mężczyzną i kobietą stworzył ich, Watykan 1986.

DzIEWIECKi M., Cielesność. Ptciowość. Seksualność, Kielce 2000.

EvDokimov P., Kobieta i zbawienie świata, Poznań 1991.

EvDokimov P., Sztuka ikony, teologia piękna, Warszawa 1999.

GoGaCz M., Elementarz metafizyki, Warszawa 1987.

GogaCz M., Ku etyce chronienia osób, Warszawa 1991;

JaRoszý́ski P., Spór o piękno, Kraków 2002;

Sw. Tomasz z Akwinu, Traktat o człowieku, oprac. S. Swieżawski, Poznań 1956.

WојтYєA K., Osoba i czyn oraz inne studia antropologiczne, Lublin 1994. 